\title{
De kunnskapsrike pasientene
}

\author{
Helseministeren ønsker seg pasienter med mer kunnskap om egen helse. Helsefremmende allmenn- \\ dannelse, pasientopplæring og brukermedvirkning gir mer kunnskapsrike pasienter. Mange mener dette \\ utelukkende er positivt, mens andre er mer skeptiske.
}

\section{Birgit Nordtug}

birgit.nordtug@hil.no

Høgskolen i Lillehammer

Helseministeren vil ha mer kunnskapsrike pasienter som tar bedre vare på sin egen helse (1). Hennes ønsker er allerede realisert av de såkalt kunnskapsrike pasientene. Vi trenger derfor ikke vente til morgendagen for å få kunnskap om helseministerens fremtidspasienter.

I denne kronikken støtter jeg meg til andre forskeres analyser og til min egen forskning. Min forskning på kunnskapsrike pasienter er avgrenset til personer med spiseforstyrrelser. Jeg har spesielt vært opptatt av hva slags funksjon forskningsrelatert kunnskap om spiseforstyrrelser kan ha i pasientenes erfaringer av seg selv og sine plager (2). Denne forskningen har relevans også i en generell diskusjon om kunnskapsrike pasienter.

\section{Idealtypen på den \\ moderne pasienten}

Betegnelsen «kunnskapsrike pasienter» brukes gjerne om dem som har skaffet seg mye kunnskap om sine egne lidelser og mulige måter å behandle disse på og som bruker kunnskapen på en aktiv måte i sitt møte med behandlingsapparatet (3).

De kunnskapsrike pasientene beskrives ofte som idealtypen på den moderne pasienten. De synliggjør at ekspertkunnskap om sykdom og behandling i vårt moderne kunnskapssamfunn ikke lenger er forbeholdt ekspertene, men er blitt tilgjengelig for pasientene selv. Sosiologen Anthony Giddens har karakterisert denne utviklingen som et demokratiseringstrekk (4). Det har økt den enkeltes deltakelse i spørsmål rundt egen helse og gitt den enkelte mer makt over sin egen livssituasjon. I dette ligger det en kunnskapsoptimisme og en tro på at kunnskap gjør sterk.

Men ikke alle deler denne kunnskapsoptimismen. Bekymring over pasienters kunnskapsrikdom er kommet fra flere hold. Enkelte allmennleger har pekt på faren for at kunnskapsrike pasienter tar over sty- ringen av behandlingen (5). Ideologikritiske helseforskere har hevdet at helsekunnskap ikke gjør pasientene myndige i spørsmål om egen helse, men disiplinerte i forhold til oppsatte standarder for god helse (6). Psykoterapeuter har tatt til orde for at sykdomskunnskapen hos kunnskapsrike pasienter ikke gir frigjørende innsikt, men heller utvider pasientenes symptomrepertoar (7).

\section{Kunnskapsoptimistene og kunnskapspessimistene}

Vi ser med andre ord konturene av to leire. På den ene siden står kunnskapsoptimistene med sin tro på at kunnskap om egen helse bidrar til positive endringer og styrking. På den andre siden finner vi kunnskapspessimistene, som er opptatt av at kunnskap om egen helse disiplinerer og fremmedgjør og er til besvær for pasienten. En slik todeling har selvfølgelig sine begrensninger og fanger ikke opp innspill som faller mellom leirene: Eksempelvis argumentet om at kunnskap om egen helse gjør sterk, men at styrkingen ikke nødvendigvis er til det gode for pasienten i samhandlingen med behandleren (8).

De to leirene tar utgangspunkt i ulike forståelser av de kunnskapsrike pasientenes evne til å håndtere sykdoms- og behandlingskunnskapen. Kunnskapsoptimistene tar utgangspunkt i en rasjonell pasient som forholder seg til kunnskapen på en autonom, analytisk og kritisk måte. Kunnskapspessimistene tar utgangspunkt i en irrasjonell pasient som styres av myndige helseaktørers standarder for hva som er helsefremmende, og av ubevisste ønsker om (sykdoms)-oppmerksomhet.

Kunnskapsoptimistiske helseaktører, som helsemyndighetene og de som tar til orde for helsefremmende allmenndannelse (9) og pasientopplæring (10) synes å være, kan derfor trekke slutninger om at kunnskap om egne lidelser er styrkende for pasienten. Likeså kan ideologikritiske helseforskere (11) og kunnskapspessimistiske psykoterapeuter (7) trekke den motsatte slutningen om at kunnskapen er til besvær for pasienten ved at den skaper en illusorisk forståelse av hva lidelsene består i.

Kunnskapsoptimistene forfekter etter mitt skjønn en naiv tro på at det er et en-til- en-forhold mellom den allmenne sykdomskunnskapen om pasientens plager og pasientens reelle plager. De tar ikke høyde for at sykdomskunnskapen har sine begrensninger når det gjelder å fange opp det individuelt særegne ved pasientens plager.

Kunnskapspessimistene ser det individspesifikke aspektet. Deres tro er imidlertid like naiv, men i motsatt retning: De overser at pasienten kan nærme seg det individuelt særegne ved plagene i resepsjon og bruk av allmenn sykdomskunnskap. Når de kunnskapsrike pasientene formidler sine plager gjennom sykdomskunnskap som de har skaffet seg på egen hånd, er det som om kunnskapspessimistene hører bare ord ord som ikke har forbindelse med pasientenes reelle plager. De kan derfor hevde at sykdomskunnskapen hos de kunnskapsrike pasientene ikke har en innsiktsgivende funksjon, men en mimeeffekt. Kunnskapen blir veiledende for pasientenes symptomfortolkninger og sykdomsfremføringer i det offentlige rommet (7).

Begge leire underkommuniserer at kunnskapsrike pasienter er både rasjonelle og irrasjonelle i kunnskapsbruken - at de både styrkes og disiplineres av kunnskapen, og at kunnskapen både kan gi frigjørende innsikter og være en kilde til symptomimitasjon. Siden denne flersidigheten mangler i forståelsen av de kunnskapsrike pasientene, fremstår pasientene som statiske i sin kunnskapsbruk. Det statiske forsterkes ved at det plagsomme ved symptomene får lite oppmerksomhet. Begge leire synes å overse at graden av symptomtrykk og hvor i sykdomsforløpet pasienten befinner seg, har betydning for resepsjon og bruk av kunnskap om egen helse.

\section{Kunnskapsrike pasienter i bevegelse}

Et sentralt funn i min forskning om spiseforstyrredes oppfatning av og bruk av kunnskap om spiseforstyrrelser var at informantene (som alle tilhørte kategorien kunnskapsrike pasienter) beveget seg mellom ulike resepsjons- og bruksposisjoner (2). Empirien (som besto av dybdeintervjuer med personer som hadde eller hadde hatt spiseforstyrrelser) ga klare indikasjoner på at bevegelsene var påvirket av symptom- 


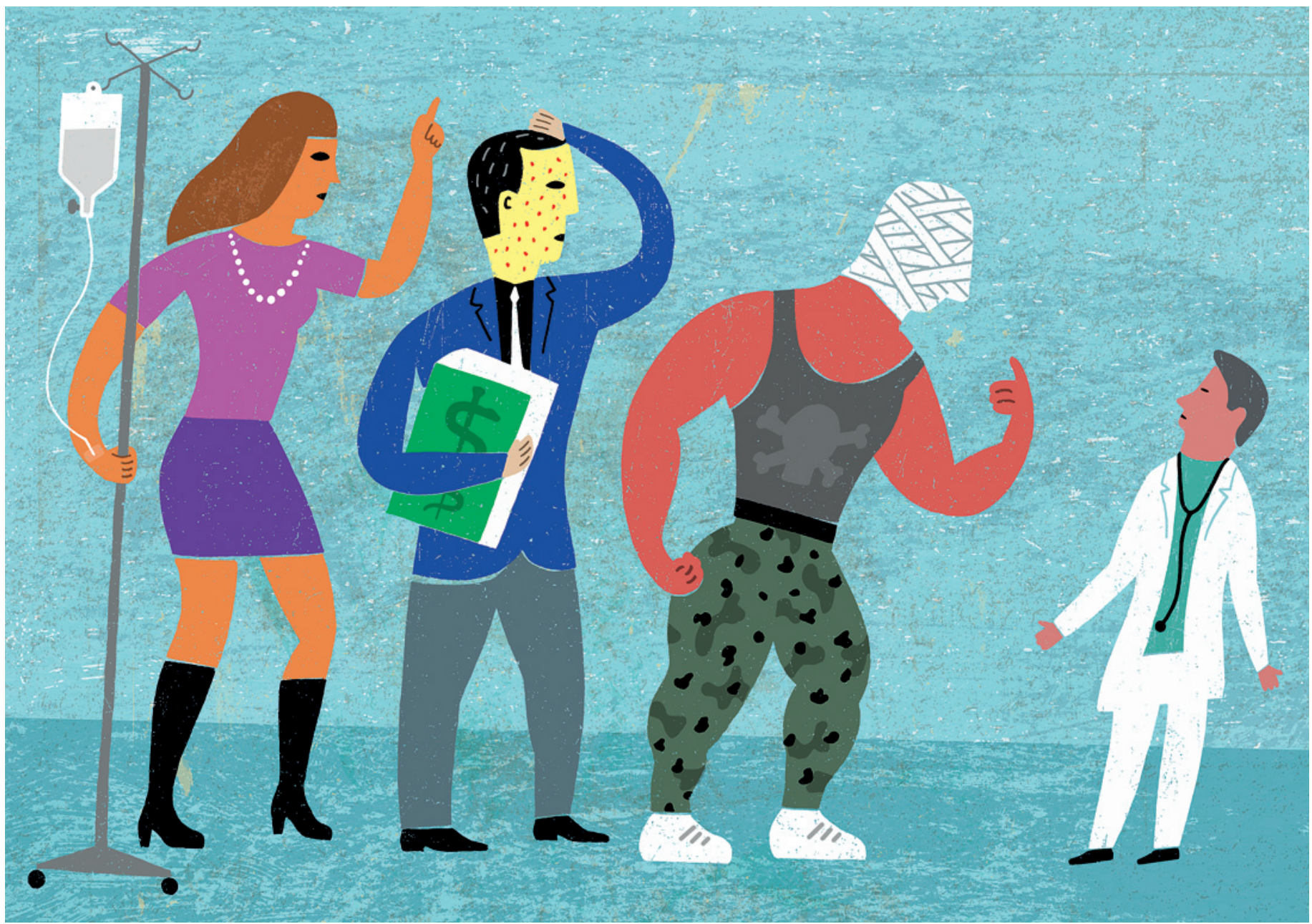

Illustrasjon Svein Størksen

bildet. Når den symptomale desperasjonen tok overhånd, var den analytiske og kritiske tilnærmingen til kunnskapen og evnen til å reflektere over symptomenes mangetydighet langt mindre enn når informantene var på høyde med plagene.

For noen av informantene var bevegelsene mellom ulike posisjoner i resepsjonen og bruken av sykdomskunnskap først og fremst knyttet til faser i sykdomsforløpet. For andre var bevegelsene mer kontinuerlige, med en veksling mellom å være usikre og sikre på kunnskapen som de mottok og anvendte, mellom nærhet og distanse til kunnskapen, mellom å åpne seg for mangfoldet av betydninger som symptomene formidlet og å forfekte én forklaring og én løsning.

Ulike posisjoner i kunnskapsbruken I antologien Den moderne pasienten er de kunnskapsrike pasientene forbundet med sikkerhetens posisjon (3). Det er en posisjon hvor den gnagende usikkerheten om hva plagene skyldes er borte. Det er denne posisjonen kunnskapsoptimistene har tro på at pasienten vil komme i når han/hun har skaffet seg tilstrekkelig kunnskap om egen helse. Men selv om usikkerheten ikke lenger hefter ved pasienten, er det mye usikkerhet også i denne posisjonen - og da forbundet med kunnskapen som pasienten har tilegnet seg. Det er ikke til å stikke under stol at mye av sykdoms- og behandlingskunnskapen på Internett og $\mathrm{i}$ andre medier er formidlet av kommersielle aktører som først og fremst er ute etter å selge sine produkter - uten at det gjøres rede for dette (5). Usikkerheten gjelder selvfølgelig også kunnskap som ikke formidles av kommersielle aktører. Kunnskapsoptimistene tar etter mitt skjønn for lett på det usikre aspektet ved helsekunnskap.

En ytterliggående variant av sikkerhetens posisjon møter vi når de kunnskapsrike pasientene opererer i mesterens posisjon. Da er de ikke i tvil om riktigheten av kunnskapen som de har skaffet seg. De er derfor lite villige til å underkaste seg andre synspunkter. Det er møtet med de kunnskapsrike pasientene i mesterens posisjon som hos enkelte allmennleger vekker bekymring for at pasientene blir for styrende $\mathrm{i}$ behand-

lingen (5). Det er interessant å merke seg at behandlere, forskere og andre som fronter prinsippet om brukerstyring synes å se bort fra denne bekymringen. Den overordnede forståelsen i deres argumentasjon er at pasienten er mester på seg selv og derfor bør styre utformingen og gjennomføringen av behandlingen (12).

I en situasjon hvor pasienten overvurderer riktigheten av kunnskapen som hun eller han har skaffet seg, ligger det en utfordring for behandleren i å skape større åpenhet hos pasienten for kunnskapens begrensninger og symptomenes mangetydighet. I en slik åpenhet er det utvilsomt en usikkerhetsdimensjon til stede. Men i en trygg behandlingsrelasjon kan denne usikkerheten bli en kilde til refleksjon over det mangetydige ved symptomene - refleksjoner som kan skape gjenkjennelse og nye erkjennelser hos pasienten.

For kunnskapspessimistene kan brukerstyringens argument om at pasienten er mester på seg selv og derfor bør styre behandlingen, være en absurd idé (13). De forbinder kunnskapsrike pasienter med tvilens posisjon - en posisjon hvor pasienten nettopp ikke er mester på seg selv og derfor søker etter kunnskap og eksperter som forventes å vite. Pasienten lykkes imidlertid ikke med å finne den som vet - fordi tvilen alltid er der. For noen fortoner denne tvilens posisjon seg som en endeløs vandring fra ekspert til ekspert fra kunnskapskilde til kunnskapskilde, slik bl.a. psykoanalytikeren Julia Kristeva har pekt på (14). Hun 
belyser dette fenomenet både fra en individualhistorisk og samtidsdiagnostisk synsvinkel.

Individualhistorisk setter hun den endeløse vandringen i sammenheng med en mangelfull internalisert autoritetsinstans som kan trygge den kunnskapen pasienten mottar. Til forskjell fra psykoanalysens klassiske, nevrotiske pasienter «lider disse nye pasientene mindre av undertrykkelse og hemmende forbud enn av mangel på referansepunkter slik at deres psykiske apparat ikke har virkelig etablert seg», skriver hun (14). Det psykiske apparatet som gjenkjenner og bedømmer relevansen av sykdomskunnskapen, har på sett og vis ikke satt seg hos disse nye pasientene. Mangelen på faste referansepunkter gjør at kunnskapsgjenkjennelsen kan utebli eller være kortvarig, og det blir en stadig leting etter relevant kunnskap og etter eksperter som kan gjøre kunnskapen relevant.

Den samtidsdiagnostiske rammen relaterer hun til begreper som høy endringshastighet, flytende normer og manglende tillit til samfunns- og familieautoriteter. Dette flytende moderne samfunnet bidrar både til å betinge og forsterke mangelen på indre referansepunkter hos disse nye pasientene, hevder hun.

En av informantene mine tok tak i problemet med å ha tillit til kunnskapen og rådene som hun fikk av ekspertene. Hun la vekt på at effekten av å tilegne seg kunnskap om spiseforstyrrelser var betinget av de relasjonene som kunnskapen var forbundet med. I de tilfellene hvor kunnskapen ble forbundet med gode relasjoner som idealiserte og legitimerte forbindelsen mellom det kunnskapen formidlet og det hun strevde med, var kunnskapen en bedringsressurs. Når kunnskapen ikke var trygget av slike relasjoner, stengte hun av for det gjenkjennende aspektet og kunn- skapen gjorde ikke noe med henne (2). I lys av Kristevas resonnement kan man si at gode behandlingsrelasjoner veide opp for mangelen på indre kunnskapstryggende referansepunkter.

\section{Samhandling og kokkesøl}

En faktor som kan trekke i negativ retning i så måte, er antallet behandlere som en pasient forholder seg til. Tverrfaglige team og andre samhandlende behandlingsnettverk på tvers av profesjoner og linjetjenester kan ha en negativ effekt på det å trygge sykdomskunnskapen og skape tiltro til behandlingen hos kunnskapsrike pasienter som mangler en slik trygghet og tro. Ideen om at mange hoder tenker og behandler bedre, kan resultere $i$ at flere kokker skaper mer søl ved å forsterke usikkerheten hos pasienter som er i tvilens posisjon. Usikkerheten kan skapes ved at flere involverte behandlere kan føre til sprikende forklaringer og råd. Flere involverte behandlere fører til økt produksjon av journaltekster og andre tekster om pasienten - tekster som i verste fall begynner å leve sitt eget liv, med manglende eller diffus forbindelse til pasientens reelle plager. Pasienten skal være temmelig sikker for ikke å bli usikker når det kommer kopier av slike selvgenererte tekster i postkassen.

I en slik situasjon er det viktig at pasienten har et behandlingsanker - én behandler som pasienten har tillit til og kan diskutere de ulike innspillene og sykdomsanalysene med. Ved at behandlingsankeret følger pasienten over tid, vil han eller hun kunne se at kunnskapsrike pasienter ikke bare er moderne mennesker med mye sykdoms- og behandlingskunnskap, men også pasienter som veksler mellom ulike posisjoner - og som trenger både kunnskapshjelp og annen hjelp.

\section{Birgit Nordtug (f. 1964)}

er førsteamanuensis i psykologi ved Høgskolen i Lillehammer.

Forfatter har fylt ut ICMJE-skjemaet og oppgir ingen interessekonflikter.

Litteratur

1. HOD Lanserer ny helseportal. Pressemelding nr. 35/2011. Helse- og omsorgsdepartementet. www.regjeringen.no/nb/dep/hod/pressesenter/ pressemeldinger/2011/lanserer-ny (19.8.2011).

2. Nordtug B. Spiseforstyrret subjektivitet i det refleksivt moderne. Doktoravhandling. Trondheim: Psykologisk institutt, Norges teknisk-naturvitenskapelige universitet, 2008.

3. Tjora A. red. Den moderne pasienten. Oslo: Gyldendal Akademisk, 2008.

4. Giddens A. Modernity and self-identity. Cambridge: Polity Press, 1991.

5. Bjerkestrand S. En stor, lykkelig familie. Tidsskr Nor Legeforen 2011; 131: 559

6. Askheim OP. Pasientopplæring og empowerment I: Brataas H, red. Sykepleiepedagogisk praksis. Pasientsentrert sykepleie på ulike arenaer. Oslo: Gyldendal Akademisk, 2011: 71-86.

7. Skårderud F. Uro. En reise i det moderne selvet. Oslo: Aschehoug, 1999

8. Hofmann B. Kunnskapsbaserte pasienter. http://konferanser.hil.no/klinikt_2008 (14.1.2012).

9. Finbråten HS, Pettersen S. Kunnskap er egenmakt. Sykepleien 2009; 97: 60-3.

10. Brataas H. red. Sykepleiepedagogisk praksis. Pasientsentrert sykepleie på ulike arenaer. Oslo: Gyldendal Akademisk, 2011.

11. Gastaldo D. Is health education good for you? Re-thinking health education through the concept of bio-power. I: Petersen A, Bunton R, red. Foucault, health and medicine. London: Routledge, 1997: 113-33

12. Valla B. Brukers medvirkning i psykoterapi behov for kompetanseutvikling. Tidsskrift for Norsk psykologforening 2010; 47: 308-14.

13. Gullestad SE. Brukermedvirkning er ikke løsningen. Tidsskrift for Norsk psykologforening 2010; 47: 547-9.

14. Kristeva J. Revolt, she said. Foreign Agents Series. Los Angeles, CA: Semiotext(e), 2002: 32.

Mottatt 15.5. 2011, første revisjon innsendt 29.1. 2012, godkjent 8.3. 2012. Medisinsk redaktør Petter Gjersvik. 